\title{
Morphogenetic Effect of L-cysteine on Pseudogymnoascus destructans and Related Species
}

\author{
Raudabaugh $\mathrm{DB}^{1,2^{*}}$ and Miller $\mathrm{AN}^{2}$ \\ ${ }^{1}$ Department of Plant Biology, University of Illinois, Urbana, Illinois 61801 USA; email: raudaba2@illinois.edu \\ ${ }^{2}$ Illinois Natural History Survey, University of Illinois, Champaign, Illinois 61820 USA
}

Raudabaugh DB, Miller AN 2014 - Morphogenetic effect of L-cysteine on Pseudogymnoascus destructans and related species. Mycosphere 5(6), 737-746, Doi 10.5943/mycosphere/5/6/4

\begin{abstract}
The addition of L-cysteine to culture media is shown to cause a morphogenetic effect on Pseudogymnoascus (Geomyces) destructans, the causal agent of bat white-nose syndrome, and on several North American Pseudogymnoascus species in vitro. Under elevated levels of L-cysteine, seven $P$. destructans isolates from various geographical localities produced yeast-like cells on amended Sabouraud's dextrose agar within 30 days at $7-10^{\circ} \mathrm{C}$. The yeast-like cells appear in semisolid, black, pigmented masses composed of ellipsoidal to obtuse cells that average $13 \times 5.5 \mu \mathrm{m}$ and demonstrate blastic development easily differentiating them from the typical curved conidia which average $6 \times 3 \mu \mathrm{m}$. The yeast-like cells were shown to revert to filamentous form when cultured on non-amended Sabouraud's dextrose agar. No yeast-like cells were visualized in four other isolates within the Pseudogymnoascus roseus complex or in two additional, distantly-related Pseudogymnoascus isolates when exposed to the same elevated levels of L-cysteine. The sensitivity of $P$. destructans to L-cysteine is believed to be a response to the reduced oxidation-reduction potential of the amended medium, but further research is needed to understand the biochemical mechanisms.
\end{abstract}

Key words - Bat white-nose syndrome - yeast-like morphology - oxidation-reduction potential

\section{Introduction}

Pseudogymnoascus (Geomyces) destructans (Blehert \& Gargas) Minnis \& D.L. Lindner, the causal agent of bat white-nose syndrome, continues to spread across the United States and Canada since its introduction to New York State in 2006 (Blehert et al. 2009, Gargas et al. 2009, Hayes 2012, Warnecke et al. 2012). Pseudogymnoascus destructans has been described as a psychrophilic (cold-loving) dermatophyte, which can cause severe skin lesions and cutaneous necrosis in bats during hibernation (Cryan et al. 2010), a time when the bat's internal body temperature is close to ambient temperature (ca. $2-10^{\circ} \mathrm{C}$ ) and its immune system is reported to be in a suppressed state (Blehert et al. 2009, Meteyer et al. 2009, Hayes 2012). In the infection process, $P$. destructans has been reported to infect hair follicles and both apocrine and sebaceous glands, but unlike most superficial dermatophytes that infect mammals, P. destructans has been reported to penetrate living tissues such as bat skin underlying connective tissue. (Blehert et al. 2009, Meteyer et al. 2009, Reichard \& Kunz 2009). 
The ability of $P$. destructans to infect bat skin underlying connective tissue (living tissue) raises the question of whether $P$. destructans has the potential to produce a yeast-like state since this altered morphological state has been suggested to increase survivability within the host (Thuy et al. 1981). Interestingly, it has previously been documented that other superficial dermatophytes such as Trichophyton rubrum and Microsporum audouinii cultured on L-cysteine gradient plates were capable of producing a yeast-like morphology (Rippon \& Scherr 1959) with an associated invasive ability in test mammals (Rippon \& Scherr 1959, Rippon et al. 1965). The mycelial to yeast transformation of the aforementioned superficial dermatophytes was attributed to the ability of Lcysteine to lower the oxidation-reduction potential of the medium (Rippon 1968), which is more akin to the reduced state of living tissue (Rippon et al. 1965). Currently, there is no documentation of a yeast-like morphology for P. destructans.

Consequently, the goal of this research was to investigate the effects of elevated L-cysteine on the morphology of $P$. destructans. Because $P$. destructans can infect living bat tissue, we hypothesize that $P$. destructans should produce a yeast-like state on elevated L-cysteine medium, while no yeast-like state should be present for the other non-invasive assayed Pseudogymnoascus species. The importance of this work is to ascertain the phenotypic potential of $P$. destructans and its potential forms on or within bat tissue.

\section{Materials \& Methods}

With the exception of the Illinois isolates, isolates examined in this study were previously used by other researchers (Johnson et al. 2013, Lorch et al. 2013, Palmer et al. 2014) and were obtained from the Center of Forest Mycology Research, or directly from other researchers. In total, seven $P$. destructans isolates were examined: three from Illinois (ILLS69284, ILLS69285, ILLS69286) and one each from Indiana (INMSC7), New York (MYA-4855, the Type culture), Pennsylvania (ILLS69283), and Slovakia (CFMR2498). As a comparison, four isolates (WSF3629, 03VT05, 05NY08, 05NY09) within the $P$. roseus complex and two distantly-related Pseudogymnoascus isolates (10NY10 and 1717-2) (Minnis \& Lindner 2013), were also evaluated for morphological changes on L-cysteine. All isolates were maintained on Sabouraud's dextrose agar (SDA) (Difco) at $7{ }^{\circ} \mathrm{C}$ under 24 hour darkness. All assay media was sterilized at $121{ }^{\circ} \mathrm{C}$ under 15 PSI for 15 minutes. All assays were replicated three times at different intervals using two replicates each time and visually screened for gross morphological culture variance with all variances noted followed by microscopic analysis.

\section{Evaluation of L-cysteine on the morphology of Pseudogymnoascus species}

Isolates were evaluated on SDA and $700 \mathrm{mg} \mathrm{L}^{-1}$ L-cysteine amended SDA media at pH 5.6 and $\mathrm{pH} 7.0$ using quadrant Petri plates. Each quadrant contained ca. $20 \mathrm{ml}$ of the following: Quadrant 1) SDA + 0.2 g FeSO4 L ${ }^{-1}$ (pH 5.6 control medium), Quadrant 2) SDA + 0.2 g FeSO4 L ${ }^{-1}$ $+4 \mathrm{~g} \mathrm{~L}^{-1} \mathrm{NaHCO}_{3}$ (sodium bicarbonate, Fisher, ca. pH 7.0 control medium), Quadrant 3) SDA +

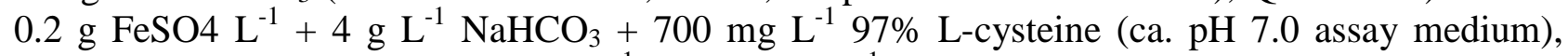
Quadrant 4) SDA + 0.2 g FeSO $4 \mathrm{~L}^{-1}+700 \mathrm{mg} \mathrm{L}^{-1} 97 \%$ L-cysteine (pH 5.6 assay medium). Supplementation of $\mathrm{NaHCO}_{3}$ (for $\mathrm{pH}$ adjustment) was added after the basal medium cooled to 55 ${ }^{\circ} \mathrm{C}$. Each quadrant was inoculated with a $5 \mathrm{~mm}$ agar plug containing actively growing mycelium, wrapped with Parafilm, and visually inspected twice per week for morphological variance. All inoculated plates were inverted two days after inoculation. Two $\mathrm{pH}$ levels were utilized to verify that any resulting morphological variations were not solely influenced by medium $\mathrm{pH}$.

\section{Analysis}

\section{Microscopic evaluation}

Light microscopic evaluation was conducted using an Olympus BX51 microscope with differential interference contrast (DIC) and equipped with an Olympus QColor 3 digital camera. Images were processed in Adobe Photoshop 7.0, and measurements were conducted using NIH 
Image version 1.63. Macroscopic photos were taken with a Cannon EOS 50 Mark II. Scanning electron microscope (SEM) sample preparations and imaging were carried out in the Frederick Seitz Materials Research Laboratory Central Facilities, University of Illinois; fungal samples were fixed in Karnovsky's fixative, gold coated (20 seconds) and imaged with a JEOL JSM-6060LV using an accelerating voltage of $15 \mathrm{kV}$. Isolate purity and yeast-like cell identity was confirmed using rDNA sequence comparison of the internal transcribed spacer (ITS) region.

\section{Molecular evaluation}

DNA was extracted by adding fresh mycelium to $200 \mu \mathrm{L} 0.5 \mathrm{M} \mathrm{NaOH}$, ground, centrifuged at $14000 \mathrm{RPM}$ for 2 minutes, and $5 \mu \mathrm{L}$ of the resulting supernatant added to $495 \mu \mathrm{L} 100 \mathrm{mM}$ Tris$\mathrm{HCl}$ buffered with $\mathrm{NaOH}$ to $\mathrm{pH}$ 8.5-8.9 (Tris-HCl-DNA extraction solution, Osmundson et al. (2013). PCR was completed on a Bio-Rad PTC 200 thermal cycler. The total reaction volume was $25 \mu \mathrm{L}\left(12.5 \mu \mathrm{L}\right.$ GoTaq ${ }^{\circledR}$ Green Master Mix, $1 \mu \mathrm{L}$ of each $10 \mu \mathrm{M}$ primer ITS4 and ITSIF, $3 \mu \mathrm{L}$ of the Tris-HCl-DNA extraction solution and 7.5 $\mu \mathrm{L}$ DNA free water). The following thermal cycle parameters were used: initial denaturation at $94{ }^{\circ} \mathrm{C}$ for 2 minutes, followed by 30 cycles of $94{ }^{\circ} \mathrm{C}$ for 30 seconds, $55^{\circ} \mathrm{C}$ for 45 seconds, $72{ }^{\circ} \mathrm{C}$ for 1 minute with a final extension step of $72{ }^{\circ} \mathrm{C}$ for 10 minutes. Gel electrophoresis (1\% TBE agarose gel stained with ethidium bromide) was used to verify the presence of a PCR product before purification using a Wizard $®$ SV Gel and PCR CleanUp System (Promega). A BigDye® Terminator 3.1 cycle sequencing kit (Applied Biosystems Inc.) was used to sequence the ITS in one direction using the ITS5 primer on an Applied Biosystems 3730XL high-throughput capillary sequencer. Identity was confirmed through nBLAST analysis.

\section{Results}

\section{Morphological response of $\boldsymbol{P}$. destructans to elevated levels of L-cysteine}

Typical colonies (grey and brown, Fig. 1A-C) and viable conidia (MYA-4855: (4.7-)5.4$6.5(-7) \times(2.1-) 2.5-3(3.2), \mathrm{N}=50$; Fig. 1D-F) were produced on all seven $P$. destructans isolates grown on SDA amended with $700 \mathrm{mg} \mathrm{L}^{-1} \mathrm{~L}$-cysteine at $7-10{ }^{\circ} \mathrm{C}$ within 30 days. Two isolates (MYA-4855 and CFMR2498) produced a macromorphology reminiscent of yeast colonies within 30 days on SDA medium supplemented with $700 \mathrm{mg} \mathrm{L}^{-1}$ L-cysteine between $7-10{ }^{\circ} \mathrm{C}$ (Fig. $1 \mathrm{G}, \mathrm{H}$ ). Microscopic examination of these smooth colonies indicated a hyphal colony composition (Fig. 1I). All seven $P$. destructans isolates produced semi-solid black masses, which varied visually from small cracks in the culture (Fig. 1J) to more prominent masses (Fig. $1 \mathrm{~K}$ ) under the $700 \mathrm{mg} \mathrm{L}^{-1} \mathrm{~L}-$ cysteine assay conditions. Microscopic examination of the semi-solid black masses (Fig. 2A) indicated a conglomeration of large connected or free cells, some of which demonstrated blastic development (Fig. 2B-E). Single aseptate cells were ellipsoidal to obtuse (6.2-)10.7-14.9(-16.9) $\mu \mathrm{m} \times(3.4-) 4.2-6.6(-8.2) \mu \mathrm{m} \quad(\mathrm{N}=50)$. Larger centrally septate cells and connected cells demonstrated constriction at the septum (14.2-)14.7-19.3(-21.5) $\mu \mathrm{m}(\mathrm{N}=10)$. The transfer of these cells to SDA resulted in mycelial growth within 4 days (Fig. 2F) and was confirmed by ITS sequence comparison to be $P$. destructans.

\section{Response of other Pseudogymnoascus species to L-cysteine}

No other examined Pseudogymnoascus species produced the aforementioned black masses or yeast-like cells. Isolates within the P. roseus complex (Fig. 3A-D) varied in response; most isolates maintained aerial mycelium while isolate 05NY09 (Fig. 3D) demonstrated a noticeable reduction of aerial mycelium on both $\mathrm{pH}$ 7.0 SDA media (SDA + sodium bicarbonate (control) and $\mathrm{SDA}+$ sodium bicarbonate $+700 \mathrm{mg} \mathrm{L}^{-1} \mathrm{~L}$-cysteine). In addition, most isolates $(75 \%)$ within the $P$. roseus complex demonstrated minimal hydrogen sulfide production (as indicated by the presence of a black precipitate within the medium) within 30 days at $\mathrm{pH} 5.6$ but not at $\mathrm{pH}$ 7.0. In contrast, both distantly-related Pseudogymnoascus isolates demonstrated substantial hydrogen sulfide production at $\mathrm{pH} 7.0$ but not at $\mathrm{pH} 5.6$ (Fig. 3E, F). No distinct hyphal variance occurred in cultures demonstrating the presence of hydrogen sulfide. Isolates 5NY8, 1717-2 and 10NY10 produced 

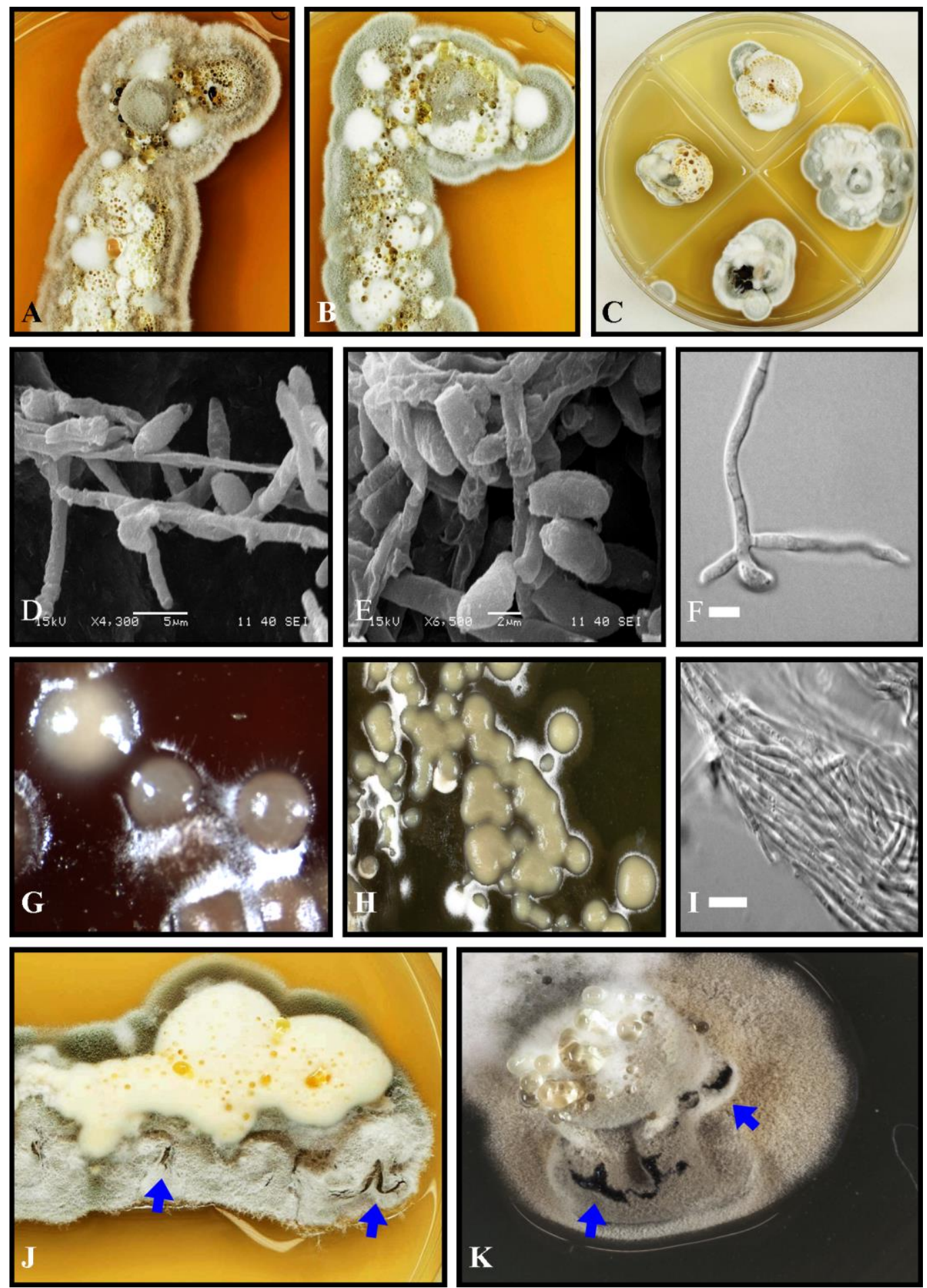

Fig. 1 - In vitro morphology of Pseudogymnoascus destructans. A. Typical brown and B. grey colony colonies of $P$. destructans New York isolate (MYA-4855, Type). C. New York isolate (MYA-4855, Type) in vitro on SDA and SDA amended media: (top) pH 5.6 SDA control medium, (right) ca. pH 7.0 SDA control medium, (bottom) ca. $\mathrm{pH} 7.0700 \mathrm{mg} \mathrm{L}^{-1} \mathrm{~L}$-cysteine assay medium, (left) $\mathrm{pH} 5.6700 \mathrm{mg} \mathrm{L}^{-1} \mathrm{~L}$-cysteine assay medium. D. Normal mycelium and conidia (SEM, 4300X). E. Normal conidiophore and conidia (SEM, 6500X). F. A germinating conidium (DIC, 2000X, scale bar $=5 \mu \mathrm{m})$. G, H. Macromorphology reminiscent of yeast colonies, Slovakian isolate (CFMR2498) and New York isolate (MYA-4855, Type) respectively. I. Microscopic analysis of the New York isolate (MYA-4855, Type) smooth colony (DIC, 2000X, scale bar $=15 \mu \mathrm{m}$ ). J, K. Semi-solid black masses emanating from the New York isolate (MYA-4855, Type) and the Pennsylvania isolate (ILLS69283), respectively, on SDA amended with $700 \mathrm{mg} \mathrm{L}^{-1}$. Arrows indicate location of semi-solid black masses. 
large connected undifferentiated vegetative hyphae in the presence of L-cysteine which were constricted at the septa (Fig. 3G-J), while no large undifferentiated hyphae were visualized for isolates 3VT5, 5NY9 and WSF3629 under the same conditions. Large undifferentiated hyphae lacking constriction at the septa were visualized in the control media for 5NY8, 1717-2 and $10 \mathrm{NY} 10$.

\section{Discussion}

\section{Morphological response of $P$. destructans to L-cysteine}

The morphology of $P$. destructans is typically described as either brownish or grayish colonies in vitro or the characteristic white (hyphal) appearance on the nose and body of bats (Gargas et al. 2009, Kubátová et al. 2011). Only two P. destructans studies have described variations to the typical phenotypes. Hyphal degeneration has been characterized in $P$. destructans in vitro at elevated $P$. destructans growth temperatures with deformed hyphae above $15{ }^{\circ} \mathrm{C}$ and irregular hyphal fragments near $18{ }^{\circ} \mathrm{C}$ (Verant et al. 2012). In addition, a histopathology examination of a dead bat described $P$. destructans hyphae with variable morphology including irregular, bulging and globose walls (Meteyer et al. 2009), indicating that $P$. destructans may demonstrate hyphal variability within bat tissue which has not been described in vitro.

While investigating $P$. destructans cultured on medium containing elevated L-cysteine (700 $\mathrm{mg} \mathrm{L}^{-1}$ ) we noted two intriguing atypical morphological variations which have not previously been reported: 1) a macromorphology reminiscent of yeast colonies (Fig. 1G, H) and, 2) yeast-like cells (Fig. 2B-E) in semi-solid black masses (Fig. 1J, K) on otherwise typical grey or brown cultures (Fig. 1A, B). The appearance of a macromorphology reminiscent of yeast colonies (Fig. 1G, H) by two P. destructans isolates (MYA-4855 and CFMR2498) were similar to MYA-4855 colonies seen on autoclaved M. lucifugus and E. fuscus wing tissue. However, the microscopic examination of these colonies showed that they were composed of typical hyphae (Fig. 1I) and not yeast-like cells. Subsequent subcultures from these colonies produced normal grey to brown colonies on SDA or $700 \mathrm{mg} \mathrm{L}^{-1}$ L-cysteine amended SDA. Although these smooth colonies were hyphal in structure, their presence demonstrates that $P$. destructans has inherent phenotypic flexibility. Additional evaluations of $P$. destructans colonies with a macromorphology reminiscent of yeast colonies may provide a more precise understand of the biology of $P$. destructans since there are links between phenotypic form and secondary metabolite production in fungi (Smedsgaard and Nielsen 2005).

The appearances of the yeast-like cells in the atypical black masses were visualized consistently on the $700 \mathrm{mg} \mathrm{L}^{-1} \mathrm{~L}$-cysteine amended media. Our initial hypothesis of the yeast-like cells was that they may represent a yeast-like contaminate in co-culture. To rule out co-culture contamination, rDNA analysis of the ITS confirmed $P$. destructans when a culture obtained by single black mass cell isolation was sequenced (data not shown). Further microscopic examination indicated that the resulting yeast-like cells were much larger than conidia (Fig. 2C). Conidial swelling has been reported for other fungi (Hoog 1987, Hayer et al. 2013); however, it was apparent that conidial swelling does not occur to this extent in P. destructans (Fig. 1F). The general morphology of these cells did not fit the rules previously described (Wickerham 1951) for defining hyphae, pseudohyphae, or intermediate hyphae. True hyphae possess cells of similar size (tip cell is not substantially longer than the previous cell) and lack prominent constrictions at the cell junctions of connected cells, characteristics which differentiate these yeast-like cells from true hyphae (Fig. 2B-D). In addition, most of the resulting yeast-like cells were aseptate or 1-septate (Fig. 2E) with blastic development (Fig. 2B-D), which is in contrast to the characteristics of intermediate hyphae and pseudohyphae.

Therefore, we concluded that the best description of these cells was indeed yeast-like and not resting spores (chlamydospores) based on the visualization of thin-walled cells undergoing blastic development, which indicated that the cells were not static, and their similarity in appearance to other budding yeast-like cells obtained from superficial dermatophytes cultured on L-cysteine gradient plates (Rippon and Scherr 1959, Rippon et al. 1965). In addition, the resulting 

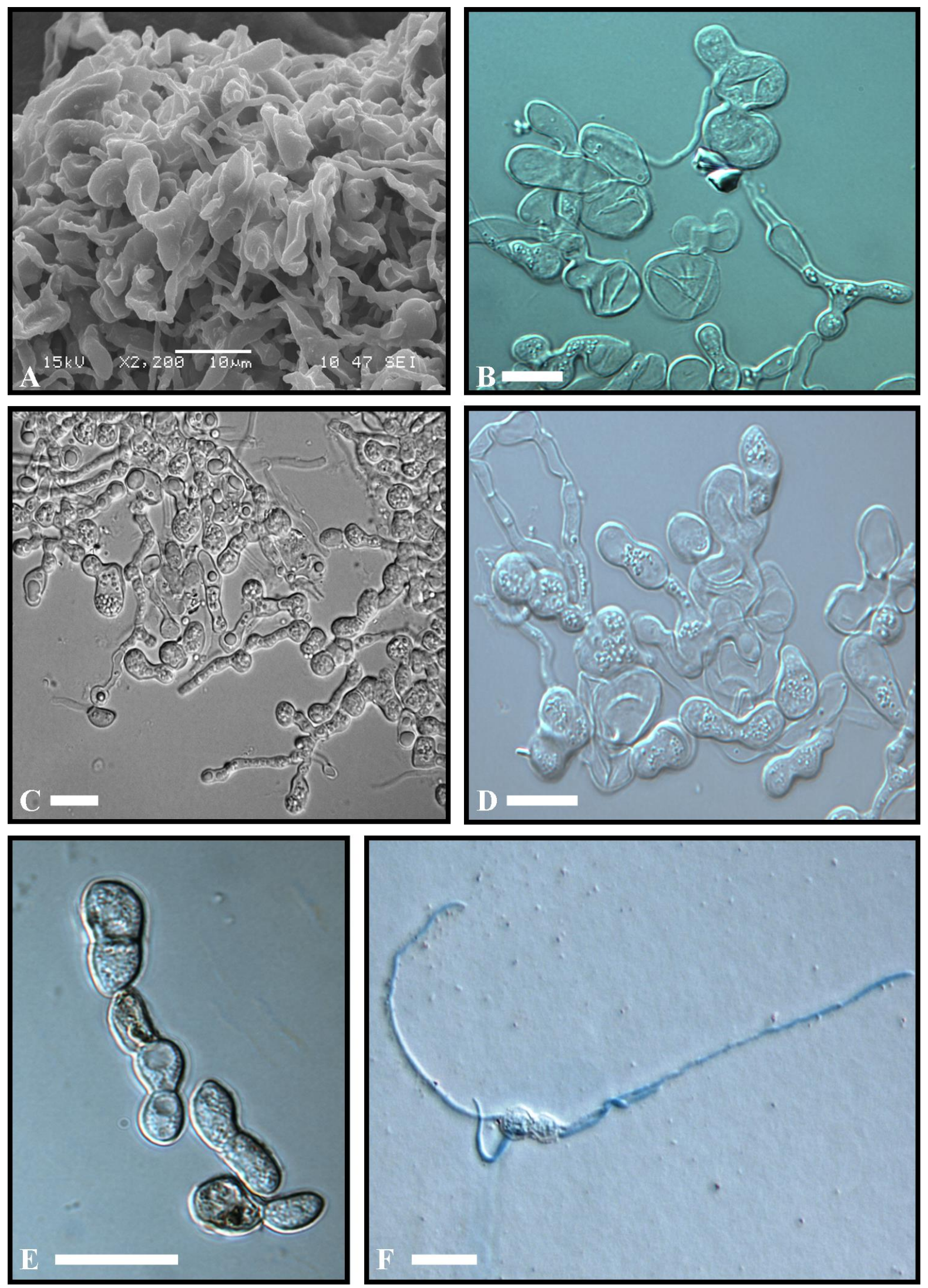

Fig. 2 - Microscopic morphology of $P$. destructans New York isolate (MYA-4855, Type) on SDA amended with $700 \mathrm{mg} \mathrm{L}^{-1}$ L-cysteine. A. SEM image demonstrating the composition of the semisolid back masses (2200X). B-E. Morphology of the P. destructans yeast-like cells (All scale bars = $10 \mu \mathrm{m})$. F. Yeast-like cell with hyphal growth four days after transfer to non-amended SDA (DIC, $800 \mathrm{X}$, scale bar $=10 \mu \mathrm{m})$. 

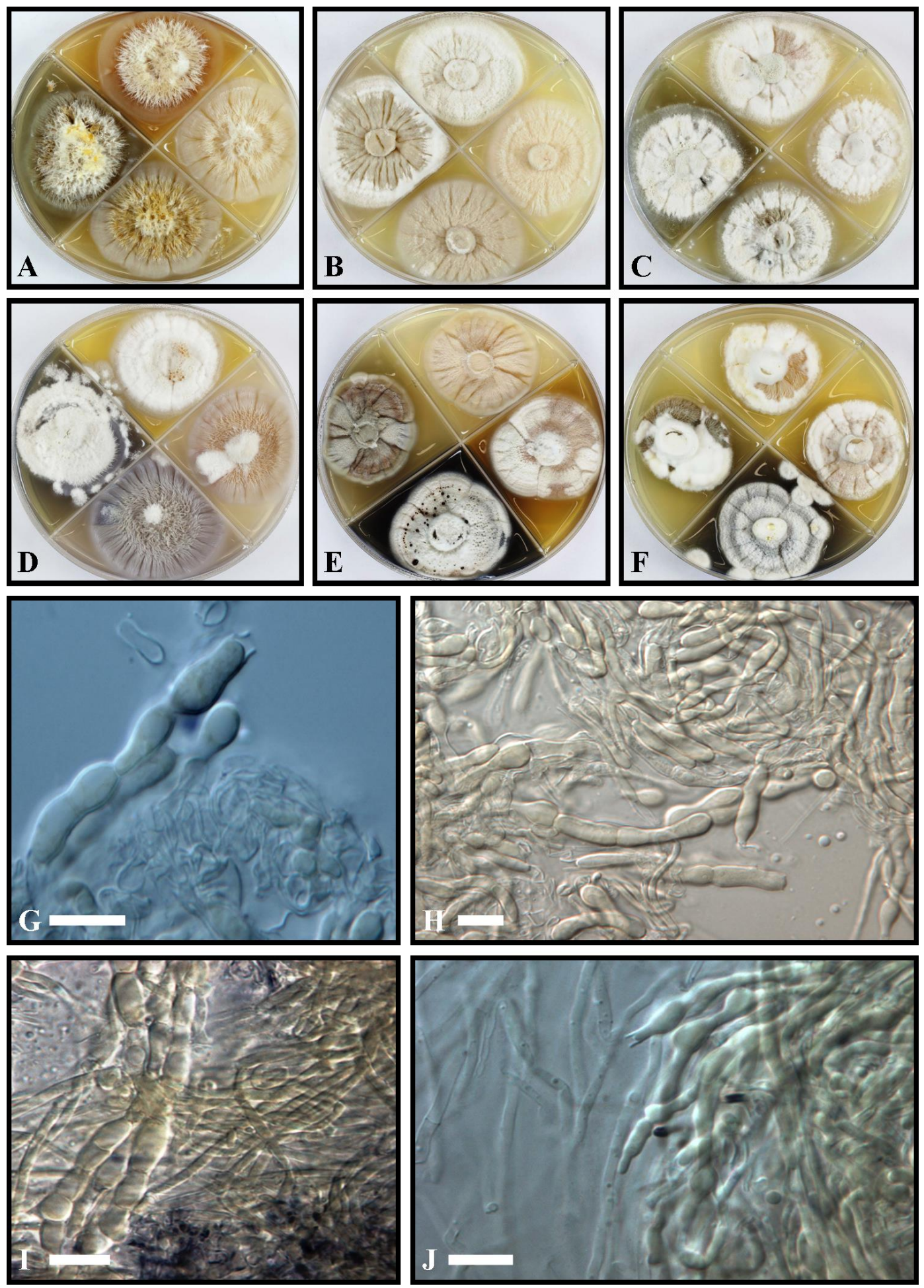

Fig. 3 - Morphology of six North American Pseudogymnoascus species on SDA and L-cysteine amended SDA. A. Isolate WSF3629, B. isolate 03VT05, C. isolate 05NY08, D. isolate 05NY09, E. isolate 10NY10, and F. isolate 1717-2 cultured in vitro on SDA (control) and SDA amended media: (top) $\mathrm{pH}$ 5.6 SDA control medium, (right) ca. $\mathrm{pH}$ 7.0 SDA control medium, (bottom) ca. $\mathrm{pH} 7.0$ $700 \mathrm{mg} \mathrm{L}^{-1} \mathrm{~L}$-cysteine assay medium, (left) $\mathrm{pH} 5.6700 \mathrm{mg} \mathrm{L}^{-1}$ L-cysteine assay medium. Black pigmentation in the medium indicated the presence of hydrogen sulfide gas. G. Large undifferentiated vegetative hyphae from isolate 1717-2 (DIC, 2000X, scale bar $=10 \mu \mathrm{m})$. $(\mathrm{H})$ Isolate 1717-2 demonstrating large and small undifferentiated vegetative hyphae (DCI, 1600X, scale bar $=10 \mu \mathrm{m})$. I. Large and small undifferentiated vegetative hyphae from isolate $05 \mathrm{NY} 08$ (DIC, 2000X, scale bar $=10 \mu \mathrm{m}$ ). J. Large and small undifferentiated vegetative hyphae from isolate 10NY10 (DIC, 2000X, scale bar $=10 \mu \mathrm{m})$. 
budding yeast-like cells reverted to filamentous form when grown on non-amended SDA, which was consistent with other superficial dermatophytes that have been shown to have an induced yeast-like state (Rippon and Scherr 1959, Rippon et al. 1965). Our results have demonstrated that elevated levels of L-cysteine $\left(700 \mathrm{mg} \mathrm{L}^{-1}\right)$ were capable of inducing a yeast-like morphology in $P$. destructans isolates and that our results were consistent with previous investigations of other superficial dermatophytes. Our results lead us to question why this phenotype has not been previously described by other authors.

The most likely reason that a yeast-like morphology for $P$. destructans has not been described resides in the type of media utilized in culturing $P$. destructans in vitro. Most if not all $P$. destructans cultured in vitro was previously done on various media that was conducive for saprophytic growth on non-living substrates, meaning that those types of media have a higher oxidation-reduction potential (ORP) than that of living tissues. Conversely, the addition of Lcysteine lowers the oxidation-reduction potential of the medium (Scherr 1957, Rippon 1968) and it has been shown it is the lower ORP environment that is responsible for altering the phenotype in other superficial dermatophytes (Rippon 1968). It has also been shown that many fungi can adapt to a reduced ORP environment (Wanke et al. 2000) and suggested that the ease in which a fungal species can adapt to a reduced ORP may indicate its potential pathogenicity (Rippon et al. 1965).

Our results are the first report of a yeast-like morphology for $P$. destructans and suggest the potential for this yeast-like state to exist within bat tissue. This yeast-like morphology may assist in the spread of the infection, increase its pathogenicity (Rippon \& Scherr 1959, Rippon et al. 1965) or it may simply assist in the survival of the fungus within the bat tissue (Thuy et al. 1981). An in-depth in vivo study is warranted but was beyond the scope of this research as our objective was to evaluate the potential for a yeast-like state, for which we have obtained visual conformation (Fig. 2B-D).

\section{Response of other Pseudogymnoascus species to L-cysteine}

Most isolates within the $P$. roseus complex (Fig. 3A-D) and both distantly-related Pseudogymnoascus isolates (Fig. 3E-F) demonstrated greater hydrogen sulfide production than $P$. destructans (Fig. 1C), which is generally believed to be produced to prevent cysteine toxicity (Barrett \& Clark 1987). The generation of hydrogen sulfide did not appear to substantially affect the overall colony morphology as no morphological variances were detected. The presence of large diameter undifferentiated hyphae in isolates 5NY8, 1717-2, and 10NY10 appear to be connected and contain similar hyphal constriction at the septum as $P$. destructans yeast-like cells (Fig. 3G-J). The function of these large diameter undifferentiated hyphae is unknown but it is possible that they represent primary hyphae with a faster growth rate (Prosser 1983) than the majority of vegetative hyphae. Alternatively, isolates 5NY8, 1717-2, and 10NY10 may require a higher concentration of L-cysteine to induce a yeast-like morphology or that these species are less adapted for growth in a lower ORP environment. Consequently, the other Pseudogymnoascus species assayed appear to be less tolerant to increased levels of L-cysteine, as indicated by the presence of hydrogen sulfide gas, and no yeast-like cells were visualized for any of the six species assayed.

\section{Conclusions}

We have shown that under elevated levels of L-cysteine, P. destructans was capable of demonstrating phenotypic plasticity by displaying 1) a macromorphology reminiscent of yeast cultures, and 2) by producing active, viable yeast-like cells capable of generating hyphal colonies when transferred to non-amended SDA. Both phenotypic responses by P. destructans appeared to be different than the responses demonstrated by six other North American species of Pseudogymnoascus. Importantly, the yeast-like cells produced by $P$. destructans are a phenotypic response that is consistent with other superficial dermatophytes and Aspergillus/Penicillium species cultured on L-cysteine gradient plates by other authors. In addition, these yeast-like cells were produced at temperatures in which bats are known to hibernate. We believe that the lower ORP environment produced by the additional of L-cysteine to the medium was responsible for the 
induction of the yeast-like cells in $P$. destructans and our research highlights the need for an in depth investigation into the biochemical and genetic effects of ORP on $P$. destructans gene expression.

\section{Acknowledgements}

The authors wish to thank the following for providing isolates used in this study: Ed Heske, Joe Kath, Dan Lindner, Joe Merritt, Barrie Overton, Andrea Porres-Alfaro, and Steve Taylor. We also want to thank Joyce Hofmann, Jean Mengelkoch, and Nohra Mateus-Pinilla for providing additional materials use in this project. This study was funded through awards given by the Illinois Department of Natural Resources State Wildlife Grants Program (Project NumberT-78-R-1) and the Section 6 Endangered and Threatened Species Program (Project Number E-54-R-1) to the Illinois Natural History Survey.

\section{References}

Barrett EL, Clark MA. 1987 - Tetrathionate reduction and production of hydrogen sulfide from thiosulfate. Microbiological Reviews 51, 192-205.

Blehert DS, Hicks AC, Behr MJ, Meteyer CU, Berlowski-Zier BM, Buckles EL, Coleman JTH, Darling SR, Gargas A, Niver R, Okoniewski JC, Rudd RJ, Stone WB. 2009 - Bat white-nose syndrome: an emerging fungal pathogen? Science 323, 227. doi:10.1126/science.1163874

Cryan P, Meteyer CU, Boyles JG, Blehert DS. 2010 - Wing pathology of white nose syndrome in bats suggests life-threatening disruption of physiology. BMC Biology 8, 135 . doi:10.1186/1741-7007-8-135

Gargas A, Trest MT, Christensen M, Volk TJ, Blehert DS. 2009 - Geomyces destructans sp. nov. associated with bat white-nose syndrome. Mycotaxon 108, 147-154.

Hayer K, Stratford M, Archer DB. 2013 - Structural features of sugars that trigger or support conidial germination in the filamentous fungus Aspergillus niger. Applied and Environmental Microbiology 79, 6924-6931.

Hayes MA. 2012 - The Geomyces fungi: ecology and distribution. Bioscience 62, 819-823.

Hoog GS. 1987 - Pleoanamorphy of yeast-like fungi and little differentiated hypomycetes. In: Sugiyama J (ed), Pleomorphic fungi: the diversity and its taxonomic implications, Elsevier Science Publishing Company, NY. pp 221-232.

Johnson LJ, Miller AN, McCleery RA, McClanahan R, Kath JA, Lueschow S, Porras-Alfaroa A. 2013 - Psychrophilic and psychrotolerant fungi on bats and the presence of Geomyces spp. on bat wings prior to the arrival of white nose syndrome. Applied and Environmental Microbiology 79, 5465-5471.

Kubátová A, Koukol O, Nováková A. 2011 - Geomyces destructans, phenotypic features of some Czech isolates. Czech Mycology 63, 65-75.

Lorch JM, Lindner DL, Gargas A, Muller LK, Minnis AM, Blehert DS. 2013 - A culture-based survey of fungi in soil from bat hibernacula in the eastern United States and its implications for detection of Geomyces destructans, the causal agent of bat white-nose syndrome. Mycologia 105, 237-252.

Meteyer CU, Buckles EL, Blehert DS, Hicks AC, Green DE, Shearn-Bochsler V, Thomas NJ, Gargas A, Behr MJ. 2009 - Histopathologic criteria to confirm white-nose syndrome in bats. The Journal of Veterinary Diagnostic Investigation 21, 411-414.

Minnis AM, Lindner DL. 2013 - Phylogenetic evaluation of Geomyces and allies reveal no close relatives of Pseudogymnoascus destructans, comb. nov., in bat hibernacula of eastern North America. Fungal Biology 117, 638-649.

Osmundson TW, Eyre CA, Hayden K, Dhillon K, Garbelotto M. 2013 - Back to basics: an evaluation of $\mathrm{NaOH}$ and alternative rapid DNA extraction protocols for DNA barcoding, geno-typing, and disease diagnostics from fungal and oomycete samples. Molecular Ecology Resources13, 66-74. 
Palmer JM, Kubátová A, Nováková A, Minnis AM, Kolarik M, Lindner DL. 2014 - Molecular characterization of a heterothallic mating system in Pseudogymnoascus destructans, the fungus causing white-nose syndrome of bats. G3: Genes Genomes Genetics, doi: $10.1534 / \mathrm{g} 3.114 .012641$

Prosser JI. 1983 - Hyphal growth patterns. In: Smith JE (ed), Fungal differentiation, Marcel Drkker, NY. pp 357-396.

Reichard JD, Kunz TH. 2009 - White-nose syndrome inflicts lasting injuries to the wings of little brown Myotis (Myotis lucifugus). Acta Chiropterologica 11, 457-464.

Rippon JW. 1968 - Monitored environment system to control cell growth, morphology, and metabolic rate in fungi by oxidation-reduction potentials. Journal of Applied Microbiology $16,114-121$.

Rippon JW, Conway TP, Domes AL. 1965 - Pathogenic potential of Aspergillus and Penicillium species. The Journal of Infectious Diseases 115, $27-32$.

Rippon JW, Scherr GH. 1959 - Induced dimorphism in dermatophytes. Mycologia 51, 902-914.

Scherr, GH. 1957 - Studies on the dimorphism of Histoplasma capsulatum. I. The role of SH groups and incubation temperature. International Society for Cell Biology 12, 92-107.

Smedsgaard J, Nielsen J. 2005 - Metabolite profiling of fungi and yeast: from phenotype to metabolome by MS and informatics. Journal of Experimental Botany 56, 273-286.

Thuy NN, Galgóczy J, Novák EK. 1981 - Morphogenetic effect of L-cysteine on dermatophytes. Acta Microbiologica Academiae Scientiarum Hungaricae 28, 347-357.

Wanke B, Lazéra M, Nucci M. 2000 - Fungal infections in the immunocompromised host. Memórias do Instituto Oswaldo Cruz 95, 153-158.

Warnecke L, Turnera JM, Bollingerb TK, Lorch JM, Misra V, Cryan PM, Wibblet G, Blehert DS, Willis CKR. 2012 - Inoculation of bats with European Geomyces destructans supports the novel pathogen hypothesis for the origin of white-nose syndrome. Proceedings of the National Academy of Sciences of the United States of America 109, 6999-7003.

Wickerham LJ. 1951 - Taxonomy of yeasts. Technical Bulletin No. 1029, United States Department of Agriculture, DC. pp $56+$ pl.5. 